\begin{tabular}{|c|c|}
\hline Title & A nodic Oxidation of Coblt in Neutral and Basic Solution \\
\hline Author(s) & Sato, Norio; Ohtsuka, Toshiaki \\
\hline Citation & $\begin{array}{l}\text { J. Electrochemical Society, 125(11), 1735-1740 } \\
\text { https://doi.org/10.1149/1.2131285 }\end{array}$ \\
\hline Issue Date & 1978-11 \\
\hline Doc URL & http:/hdl.handle.net/2115/62201 \\
\hline Rights & $\begin{array}{l}\text { (1) The Electrochemical Society, Inc. 1978. All rights reserved. Except as provided under U.S. copyright law, this work } \\
\text { may not be reproduced, resold, distributed, or modified without the express permission of The Electrochemical Society } \\
\text { (ECS). The archival version of this work was published in J. Electrochem. Soc. } 1978 \text { volume 125, issue 11, 1735-1740. }\end{array}$ \\
\hline Type & article \\
\hline File Information & J.Electrochem.Soc.125,1735-174O(1978) A nodic oxidation of cobalt .pdf \\
\hline
\end{tabular}

Instructions for use 
30, 2724 (1956); 31, 2328 (1957); 32, 66 (1958).

33. T. J. Lennox and I. P. Peterson, Corrosion, 29, 406 (1973).

34. H. W. Pickering and R. P. Frankenthal, NACE, Houston, Texas, p. 261 (1974)

35. E. McCafferty, This Journal, 121, 1007 (1974).

36. M. Pourbaix, "Localized Corrosion MACE," p. 12 (1974).
37. J. C. Rowlands, Br. Corros. J., 11, 195 (1976).

38. D. A. Jones and N. D. Greene, Corrosion, 25, 367 (1969).

39. E. A. Lizlovs, This Journal, 117, 1335 (1970).

40. M. M. Kurtepov, M. N. Fokin, V. K. Zhuravlev, and V. I. Oreshkin, "Corrosion and of Construction Alloys Protection," p. 27, "Science," Moscow (1966) (in Russian).

\title{
Anodic Oxidation of Cobalt in Neutral and Basic Solution
}

\author{
Norio Sato* and Toshiaki Ohtsuka \\ Electrochemistry Laboratory, Corrosion Research Group, Faculty of Engineering, \\ Hokkaido University, Sapporo 060, Japan
}

\begin{abstract}
The anodic oxidation and anodic oxide films of cobalt have been studied in borate buffer solutions in the $p H$ range from 7 to 11 . The anodic polarization curve shows the active dissolution, primary passivity, secondary passivity, tertiary passivity, and transpassivation. It is also shown that the anodic oxide film is hydrated oxide of $\mathrm{COO}$ in the primary passive region, bilayered oxide $\mathrm{CoO} / \mathrm{Co}_{3} \mathrm{O}_{4}$ in the secondary passive region, and bilayered oxide of $\mathrm{CoO} / \mathrm{Co}_{2} \mathrm{O}_{3}$ in the tertiary passive and transpassive regions. The dissolution current of the anodic oxide film in the secondary and tertiary passive regions is much smaller than that in the primary passive region. By cathodic reduction the outer $\mathrm{Co}_{2} \mathrm{O}_{3}$ layer is first converted to $\mathrm{Co}_{3} \mathrm{O}_{4}$ and then reduced further to hydrated $\mathrm{Co}^{2+}$ ions before the inner $\mathrm{CoO}$ layer is reduced to metallic cobalt.
\end{abstract}

Early this century, it was reported that cobalt was passivated chemically in concentrated nitric acid and electrochemically in alkaline solutions (1). Later, Grube (2) found three potential arrests in galvanostatic transients of anodic oxidation of cobalt in alkaline solutions and attributed them to the formation of $\mathrm{Co}_{3} \mathrm{O}_{4}, \mathrm{Co}_{2} \mathrm{O}_{3}$, and $\mathrm{CoO}_{2}$. El-Wakkad and Hickling (3) also found the three potential arrests but described them as corresponding to $\mathrm{CoO}, \mathrm{Co}_{2} \mathrm{O}_{3}$, and $\mathrm{CoO}_{2}$. Recently, by use of potential sweeps, Tikkanen et al. (4) observed three current peaks in the anodic polarization curves of cobalt in alkaline solutions and assumed the formation of $\mathrm{CoO}, \mathrm{Co}_{3} \mathrm{O}_{4}$, and $\mathrm{Co}(\mathrm{OH})_{3}$. Other potentiostatic studies (5-7) carried out afterward have also suggested the successive formation of cobalt oxides of different oxidation states in agreement with the thermodynamic predictions $(8-9)$. No direct evidence, however, has been provided for the composition of anodic oxide films on cobalt, except that Leidheiser et al. $(10-11)$ detected by Mössbauer spectroscopy cobalt(II) and cobalt(III) ions in the anodic oxide films.

In our previous paper (12) the thickness of anodic oxide films on cobalt has been measured by in situ ellipsometry in neutral borate solution. This paper deals with the anodic polarization curve and the composition of anodic oxide films on cobalt in neutral and alkaline solutions.

\section{Experimental}

The specimen was prepared from cobalt rods of 99.99\% purity (Johnson-Matthey Company, Limited) into polycrystalline sheets, $0.8 \mathrm{~mm}$ thick and 5 or 10 $\mathrm{cm}^{2}$ surface area. It was mechanically polished, annealed for $100 \mathrm{hr}$ at $390^{\circ} \mathrm{C}$ in vacuum, and electropolished at $0.45 \mathrm{~A} / \mathrm{cm}^{2}$ in a mixture of $60 \%$ perchloric acid and pure acetic acid $(5: 1)$ at $3^{\circ} \sim 5^{\circ} \mathrm{C}$. The electrolytic cell was a two-compartment four-electrode cell of $50 \mathrm{~cm}^{3}$ capacity connected with four

- Electrochemical Society Active Member Key words: metals, anode, potential, passivity. separate solution reservoirs. It had a Luggin capillary to a saturated calomel reference electrode and two platinum counterelectrodes, one in the specimen compartment and the other in the countercompartment. The solutions, prepared from doubly distilled water and analytical grade reagents, were mixtures of 0.30 $\mathrm{mole} / \mathrm{dm}^{3}$ boric acid and $0.075 \mathrm{~mole} / \mathrm{dm}^{3}$ sodium borate solutions, and their $p \mathrm{H}$ was adjusted by changing the mixing ratio and, if necessary, by adding a small amount of sodium hydroxide. Before transfer into the cell, the solutions were deoxygenated practically completely by injecting purified nitrogen gas for more than 24 hr.

The specimen in the cell was first cathodically reduced at a constant current of $10 \mu \mathrm{A} / \mathrm{cm}^{2}$ for $20 \mathrm{~min}$ in a borate solution of $p H \quad 8.42$ to obtain the oxidefree surface, and after careful exchange of solution under nitrogen atmosphere it was anodically oxidized potentiostatically for $1 \mathrm{hr}$ at a given potential in a given solution. The solution was then drawn out for chemical analysis to determine the amount of cobalt dissolution by a colorimetric nitro- $R$ salt method sensitive to $5 \mu \mathrm{g} / \mathrm{dm}^{3}$. The oxidation was repeated for various potentials and $\mathrm{pH}$ solutions starting every time from the cathodically reduced surface at $\mathrm{pH}$ 8.42. In some experiments the time of anodic oxidation was extended up to $24 \mathrm{hr}$ and the solution was chemically analyzed for cobalt for one hour to determine the time change of cobalt dissolution at constant potential.

Cathodic reduction experiments were carried out in which the oxidized specimen, immediately after oxidation, was reduced by a constant cathodic current of 5 or $10 \mu \mathrm{A} / \mathrm{cm}^{2}$ for different periods of time and the solution, immediately after the current was off, was taken out for chemical analysis to determine the amount of cobalt dissolved as a function of cathodic charge passed.

All measurements were performed at $20^{\circ} \pm 0.5^{\circ} \mathrm{C}$ All electrode potentials were measured in reference to a saturated calomel electrode and converted to 
the standard hydrogen electrode potential scale $E_{\mathrm{SHE}}$ or the hydrogen electrode scale in the same solution $E_{\text {HESS }}=E_{\mathrm{NHE}}+0.058 \mathrm{pH}$.

\section{Results}

Oxide-free reference surface.-The oxide-flee surface, with which coulometric measurements were carried out, was obtained by cathodic reduction of the specimen at a constant current $10 \mu \mathrm{A} / \mathrm{cm}^{2}$ for 20 min in a borate solution at $p H$ 8.42. The absence of oxide films on the cathodically reduced surface appears evident from measurements of galvanostatic reduction-oxidation cycles, in which the first oxidation curve for a surface prepared by cathodic reduction of the electropolished surface was consistent with the second oxidation curve obtained after cathodic reduction of the anodically oxidized surface. This reproducible surface is suggested to be free from oxides. It has also been shown by ellipsometry that the anodic oxide films on cobalt were completely removed by cathodic reduction (12) at $\mathrm{pH} 8.42$.

Anodic oxidation.-The anodic polarization curves of cobalt in borate solutions at $\mathrm{pH} 7 \sim 11$ are shown in Fig. 1, where the anodic currents represent the nearly stationary values observed $1 \mathrm{hr}$ after the start of potentiostatic oxidation each with the oxide-free surface. Figure 2 shows the amount of cobalt dissolved during $1 \mathrm{hr}$ oxidation as a function of potential. In these two figures, the three different degrees of pas-

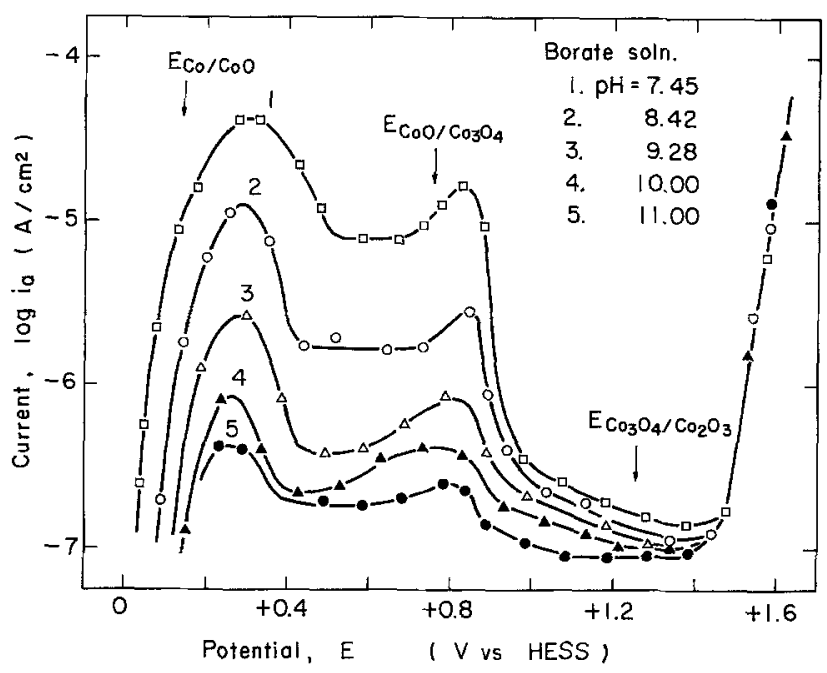

Fig. 1. Anodic current/potential curves of cobalt in borate solutions. The current is measured $\mathrm{l} \mathrm{hr}$ after the start of potentiostatic oxidation of the oxide-free surface.

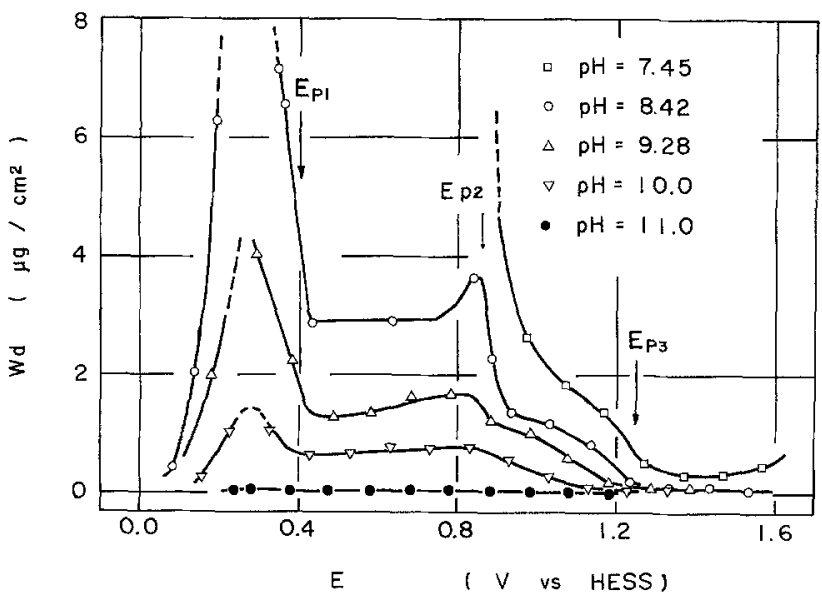

Fig. 2. Anodic $1 \mathrm{hr}$ dissolution/potential curves of cobalt in borate solutions. The amount of dissolution $W_{d}$ is measured for $\mathrm{l} \mathrm{hr}$ of potentiostatic oxidation of the oxide-free surface. sivity can be distinguished; the primary passive region I extending from +0.4 to $+0.8 \mathrm{~V}$, the secondary passive region II from +0.9 to $+1.25 \mathrm{~V}$, and the tertiary passive region III from $+1.25 \mathrm{~V}$ to about $+1.6 \mathrm{~V}$ in the HESS potential scale referred to the hydrogen electrode in the same solution. Transpassivation appears to occur at more anodic potential. The critical potential for anodic oxygen evolution is about $+1.45 \mathrm{~V}$ (HESS), which exceeds its equilibrium potential by about $0.37 \mathrm{~V}$. The Tafel line for the oxygen electrode reaction in Fig. 1 gives kinetic parameters; $(\partial E / \partial$ log i) $\mathrm{pH}_{\mathrm{H}}=75 \mathrm{mV}$ and $(\partial \log i / \partial \mathrm{pH})_{\mathrm{t}} \doteqdot 1$.

The transpassive dissolution at more anodic potentials is shown in Fig. 3, where the SHE potential scale is used. It is noticed that the critical potential for transpassivation is almost independent of $p \mathrm{H}$, being about $+1.1 \mathrm{~V}$ (SHE) in the $p H$ range from 7 to 11 .

To compare the anodic current with the dissolution rate of cobalt in the same scale, the anodic current after $1 \mathrm{hr}$ and the dissolution current averaged for $1 \mathrm{hr}$ following the initial $1 \mathrm{hr}$ oxidation at constant potential are plotted as a function of potential in Fig. 4. In the passive region $I$, the anodic current reached the steady value within $1 \mathrm{hr}$ and is equal to the dissolution current of cobalt as cobalt(II) ion. In the passive regions II and III, however, the anodic current does not reach the steady state in $1 \mathrm{hr}$. Furthermore, the anodic current in region III is larger than the dissolution current as (III) ions, indicating

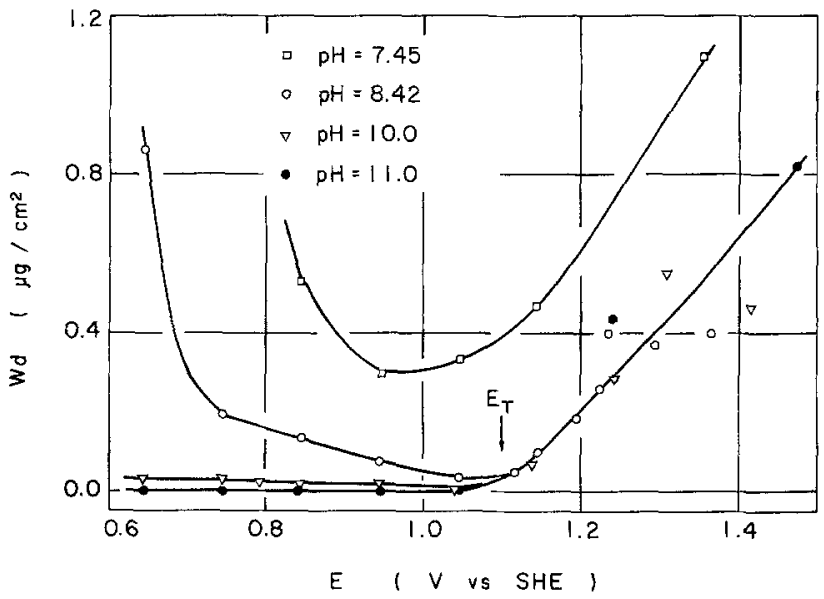

Fig. 3. Anodic $1 \mathrm{hr}$ dissolution/potential curve of cobalt in possive and transpassive potential regions in borate solutions.

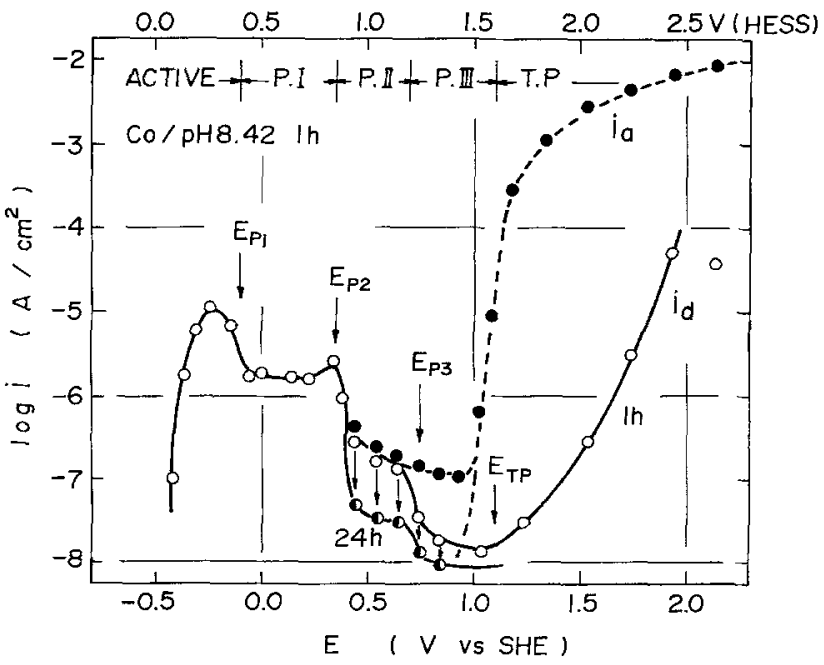

Fig. 4. Anodic current/potential and dissolution-current/potential curves of cobalt in borate solution at $\mathrm{pH} 8.42$. The anodic current (e) is measured $1 \mathrm{hr}$ after the start of axidation, and the dissolution current is the average for 1 hr following first $1 \mathrm{hr}(\mathrm{O})$ and $24 \mathrm{hr}(\triangle)$. 
that the thickening of the anodic oxide is in progress even after $1 \mathrm{hr}$. In the transpassive region, the anodic current mostly carries oxygen at more anodic potentials, and the transpassive dissolution current, though increasing with potential, takes only a diminutive part of the total anodic current. The anodic oxygen evolution current first increases with potential following a Tafel relation and then approaches a limiting current which increases with $p H$.

To examine how much time to take before the steady state is reached in passive regions II and III, $24 \mathrm{hr}$ oxidation was carried out at constant potential. Figure 5 shows the anodic current and the cobalt dissolution current both decreasing with time of oxidation toward the steady values in $24 \mathrm{hr}$. It is evident that at the steady state the anodic current is equivalent to the cobalt dissolution rate as cobalt(II) ion in region II and as cobalt (III) ion in region III.

It has been shown in Fig. 1 and 2 that the $p H$ dependence of cobalt dissolution is much larger in active and passive I regions than in passive regions II and III. Figure 6 shows the $p H$ dependence of the active peak current $i_{\mathrm{am}}$ and of the potential-independent dissolution current $i_{\mathrm{p} 1}$ in passive region $\mathrm{I}$, leading for a $p H$ range $7.4 \sim 9.4$ to the following relations; log $i_{\mathrm{am}}=0.34-0.63 \mathrm{pH}\left(\mathrm{A} / \mathrm{cm}^{2}\right)$ and $\log i_{\mathrm{p} 1}=-0.44-$ $0.63 \mathrm{pH}\left(\mathrm{A} / \mathrm{cm}^{2}\right)$. In passive regions II and III, it was difficult to determine the $\mathrm{pH}$ dependence of the steady-state dissolution current because of the extremely small dissolution rate in this $\mathrm{pH}$ range.

To estimate the amount of anodic oxide formed in $1 \mathrm{hr}$, measurements were carried out of the anodic charge, $Q_{f}$, accumulated in the anodic oxide film, which could be obtained by subtracting the charge equivalent to the amount of dissolution as cobalt (II) or (III) ion from the total anodic charge passed. Figure 7 shows the anodic film charge $Q_{\mathrm{f}}$ as a function of potential. Evidently, the anodic film starts to form in the potential region of active dissolution. The amount of the anodic film charge is nearly potential independent in passive region I, but it increases with potential in passive regions $I I$ and III.

Cathodic reduction of anodic oxide films.-Figure 8 shows the galvanostatic-cathodic reduction of the anodic oxide films, where the potential decay and the amount of cobalt(II) ion dissolved from the films are plotted as a function of cathodic charge passed. In this figure, the film is formed for $1 \mathrm{hr}$ at a given potential in the solution of $\mathrm{pH} 10.0$ and reduced by a cathodic current of $10 \mu \mathrm{A} / \mathrm{cm}^{2}$ in the solution of $\mathrm{pH}$ 8.42. Obviously, the anodic film formed in passive

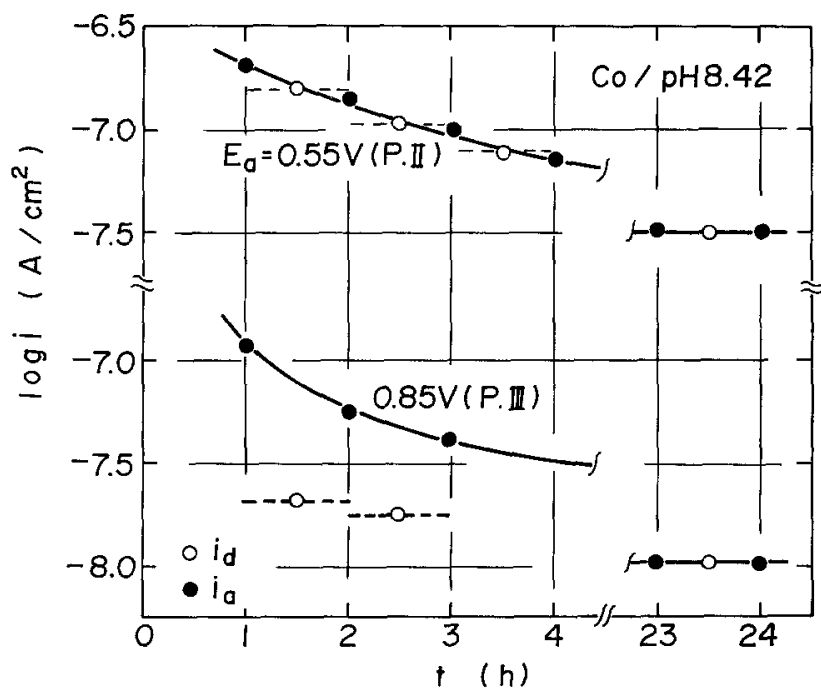

Fig. 5. Variation of anodic current $i_{\mathrm{a}}$ and dissolution current $i_{\mathrm{d}}$ with time for cobalt at constant potential in passive regions 11 and III in borate solution $\mathrm{pH} \mathbf{8 . 4 2}$. The dissolution current is the average for $1 \mathrm{hr}$.

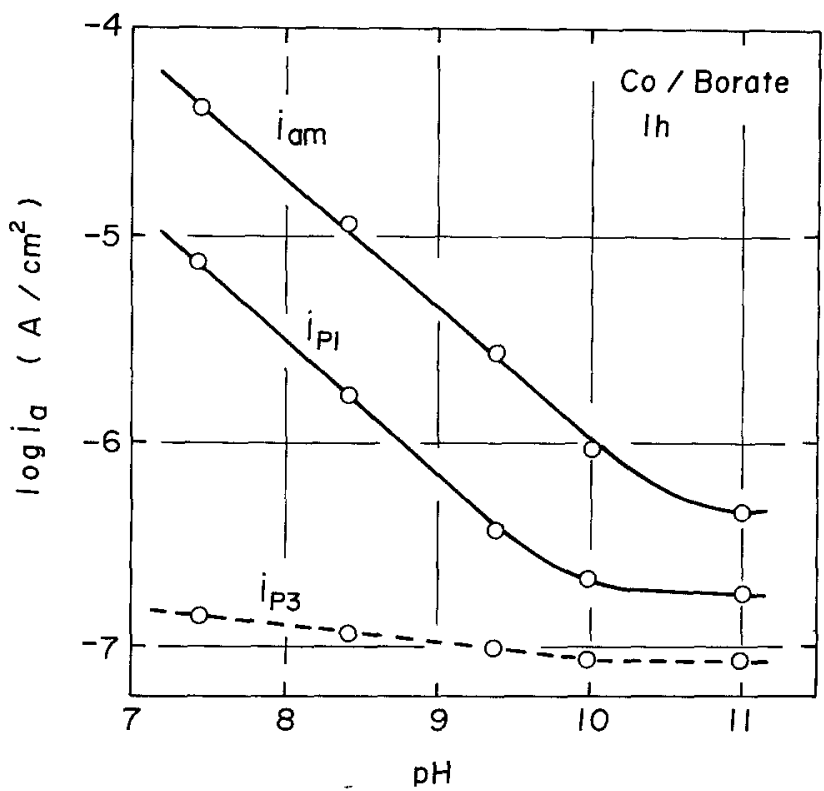

Fig. 6. Variation of active peak current $i_{\mathrm{am}}$, primary passivity current $i_{\mathrm{p} 1}$, and tertiary passivity current $i_{\mathrm{p} 3}$ with $\mathrm{pH}$ for anodic oxidation of cobalt in borate solutions. The current is measured $\mathrm{I} \mathrm{hr}$ after the start of oxidation.

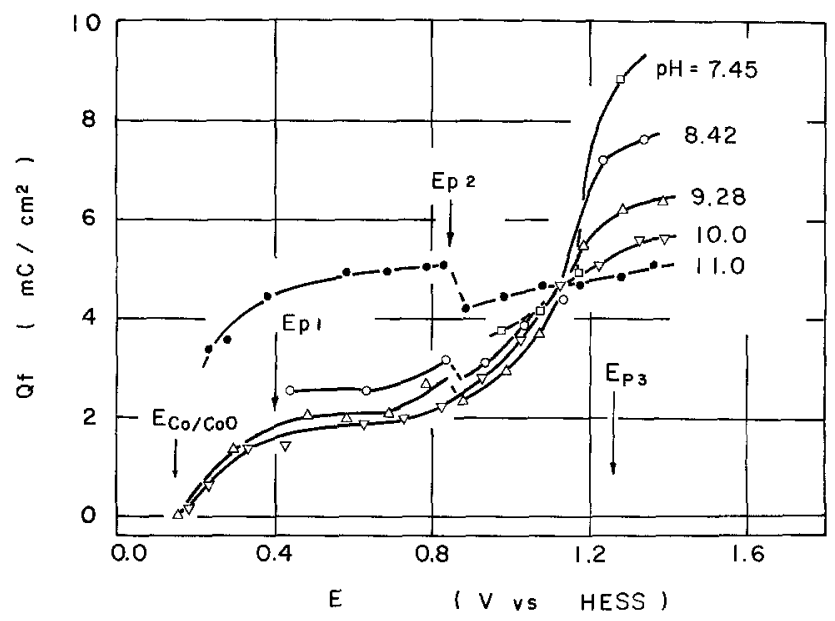

Fig. 7. Anodic film-charge/potential curves of cobalt in borate solutions. The film charge $Q_{f}=Q_{a}-Q_{d}$, where $Q_{a}$ is the anodic charge passed for $1 \mathrm{hr}$ and $Q_{d}$ the charge equivalent to cobalt dissolution $\left(Q_{\mathrm{d}}=W_{\mathrm{d}} / 2 \mathrm{~F}\right)$.

region I shows a rapid cathodic potential decay to an oxide reduction potential $-0.55 \mathrm{~V}$ (SHE) slightly more noble than the final potential and no cobalt(II) ion is produced in the solution during the cathodic reduction, indicating that the primary passive film of cobalt(II) oxide or hydroxide is reduced to metallic cobalt. The film formed in passive region III, however, shows a definite arrest in the potential decay and produces cobalt(II) aquo-ions in the solution during its cathodic reduction, indicating that a higher valent cobalt oxide is reduced to soluble cobalt(II) ions.

The cathodic dissolution of the film as cobalt(II) ions, which occurs only with the film formed in passive regions II and III, differs with different solution $\mathrm{pH}$ in which cathodic reduction is carried out. Figure 9 shows the cathodic dissolution curves in different $p H$ solutions for the anodic oxide film formed at a constant potential in passive region III in the solution of $p \mathrm{H} 10.0$. After an induction period of about $0.1 \mathrm{mC} /$ $\mathrm{cm}^{2}$, the amount of cobalt(II) ion dissolution increases nearly linearly with the cathodic charge passed and then gradually approaches a maximum value $W_{d}$ max The broken line in Fig. 9 refers to the theoretical 


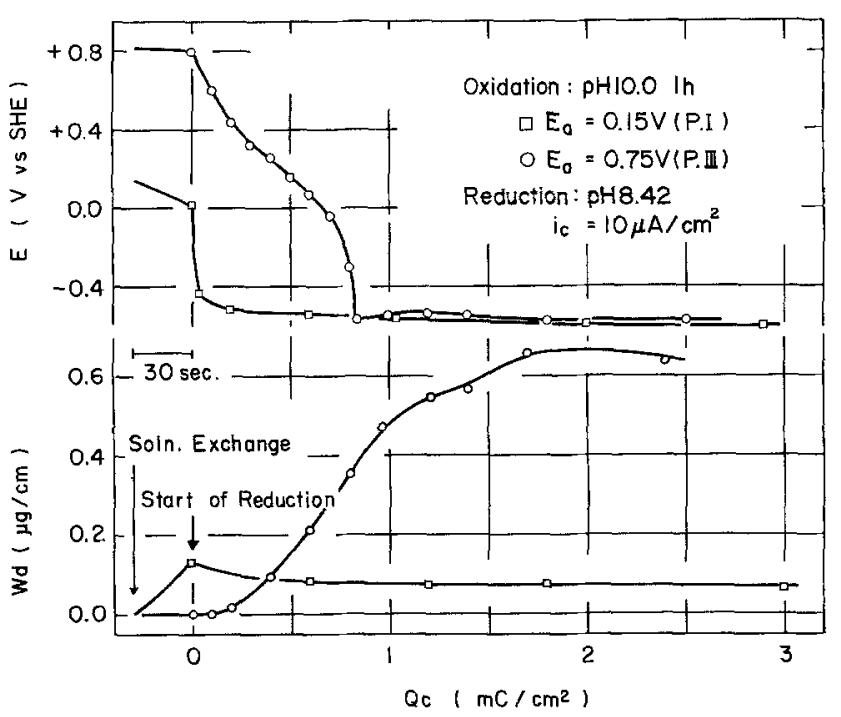

Fig. 8. Variation of potential and amount of cobalt(II) dissolution with cathodic charge passed during galvanostatic reduction of anodic oxide films formed in passive regions $\mathrm{I}$ and III. The film,

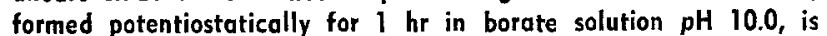
reduced by cathodic current $10 \mu \mathrm{A} / \mathrm{cm}^{2}$ in borate solution $\mathrm{pH}$ 8.42.

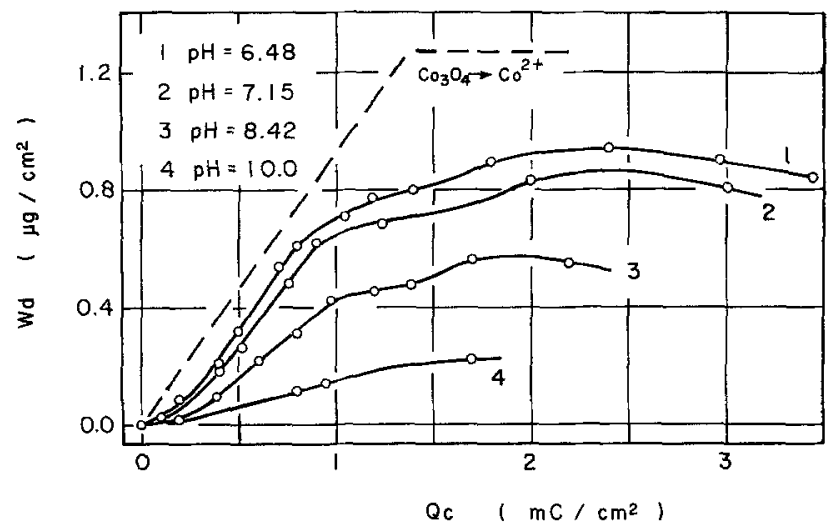

Fig. 9. Cathodic reduction curves of an anodic oxide film on cobalt in borate solutions $\mathrm{pH} 6 \sim 10$. The film, formed for $1 \mathrm{hr}$ at $+0.75 \mathrm{~V}$ (SHE) at $\mathrm{pH} \mathrm{10}$, is reduced by cathodic current $10 \mu \mathrm{A} /$ $\mathrm{cm}^{2}$ to measure the amount of dissolution $W_{d}$ os a function of cathodic charge $Q_{c}$ in various solutions.

cathodic dissolution of stoichiometric $\mathrm{Co}_{3} \mathrm{O}_{4}, \mathrm{Co}_{3} \mathrm{O}_{4}+$ $8 \mathrm{H}^{+}+2 e \rightarrow 3 \mathrm{Co}^{2}++4 \mathrm{H}_{2} \mathrm{O}$, and hence its slope can be used as a reference of differential current efficiency $\eta$ for cathodic dissolution of the film. A limiting value in the broken line represents the total amount of cobalt $W_{\mathrm{d}^{\mathrm{T}}}$ in the film assuming a single layer of $\mathrm{Co}_{3} \mathrm{O}_{4}$. As shown in Fig. 10, both differential current efficiency $\eta$ and maximum amount of dissolved cobalt(II) ion $W_{\mathrm{d}} \max$ increase with decreasing $p \mathrm{H}$. Notice that $\eta$ reaches $100 \%$ at $p H \quad 6.48$, though $W_{d} \max$ is smaller than $W_{d}{ }^{T}$ even at this $p H$. The cathodic current density in a range $2 \sim 50 \mu \mathrm{A} / \mathrm{cm}^{2}$ has a slight influence on $W_{d}$ max but produced no effect on $\eta$.

Because of the differential current efficiency $\eta=$ $100 \%$, the solution of $\mathrm{pH} 6.48$ and the current density of $5 \mathrm{\mu A} / \mathrm{cm}^{2}$ were employed as a standard cathodic reduction method to measure the composition of the anodic oxide films formed at different potentials in the solution at $\mathrm{pH}$ 8.42. Results are shown in Fig. 11, where the broken line again refers to the cathodic dissolution of $\mathrm{Co}_{3} \mathrm{O}_{4}$. Noticeably, the film formed at $+0.65 \mathrm{~V}$ ( $\mathrm{SHE}$ ) in passive region II dissolves along the theoretical $\mathrm{Co}_{3} \mathrm{O}_{4}$ dissolution curve without any induction charge for cathodic dissolution, indicating that at least the outer part of the film is $\mathrm{Co}_{3} \mathrm{O}_{4}$ or $\mathrm{Co}_{3} \mathrm{O}_{4} \cdot n \mathrm{H}_{2} \mathrm{O}$. The film formed at $+0.85,1.05$, and

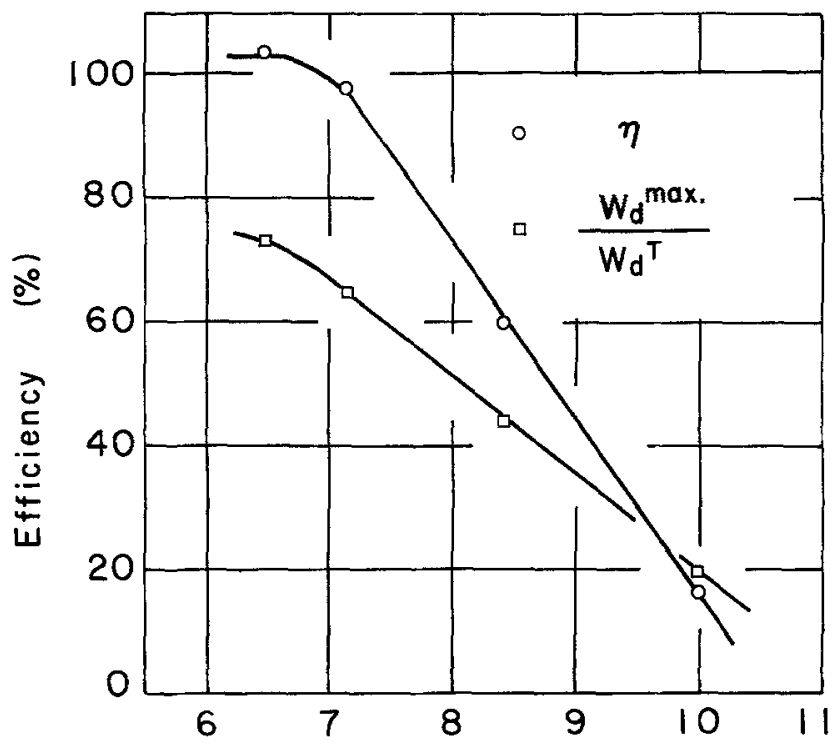

$\mathrm{pH}$

Fig. 10. Differential current efficiency $\eta$ and integral efficiency $W_{d} \max / W_{d}{ }^{T}$ of reductive dissolution of an anodic oxide film on cobalt os a function of solution $\mathrm{pH}$ used for cathodic reduction.

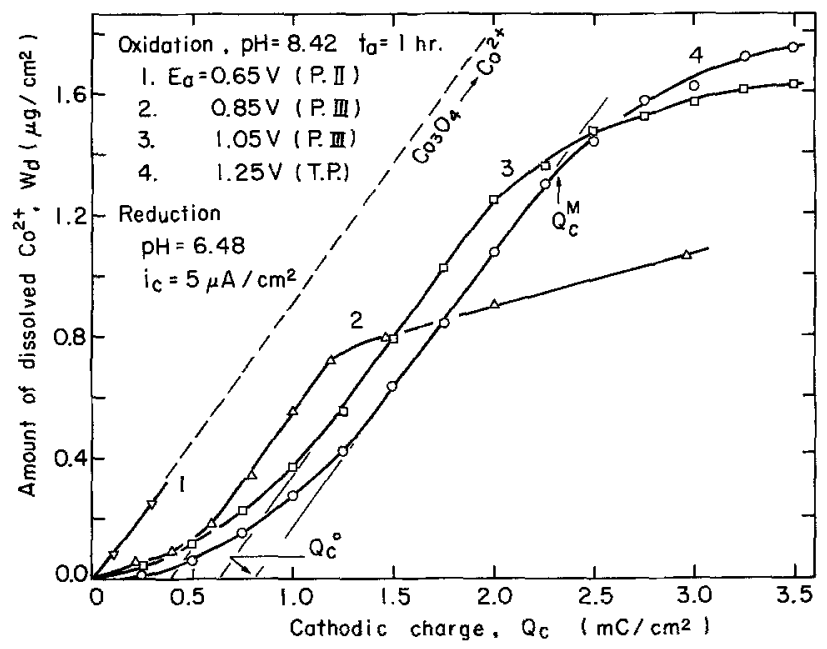

Fig. 11. Cathodic reduction curves of anodic oxide films on cobalt in possive regions II $\left(+0.65 \mathrm{~V}_{\mathrm{SHE}}\right), \quad$ III $(+0.85 \mathrm{~V}$ and $\left.+1.05 \mathrm{~V}_{\mathrm{SHE}}\right)$ and in transpassive region $\left(+1.25 \mathrm{~V}_{\mathrm{SHE}}\right)$. The film, formed for $1 \mathrm{hr}$ at $\mathrm{pH} 8.42$, is reduced by cathodic current $5 \mu \mathrm{A} /$ $\mathrm{cm}^{2}$ in borate solution $\mathrm{pH} 6.48$.

$1.25 \mathrm{~V}$ (SHE) in passive region III, however, requires an induction charge $Q_{c}{ }^{\circ}$ before the cathodic dissolution occurs at the same rate as $\mathrm{Co}_{3} \mathrm{O}_{4}$, indicating that the outer part of the film is in the oxidation state higher than $\mathrm{Co}_{3} \mathrm{O}_{4}$ or contains a significant amount of cobalt ion vacancy, $\mathrm{Co}_{3-\Delta} \mathrm{O}_{4}$. Furthermore, it is found that the induction charge $Q_{c}{ }^{\circ}$ and the charge $Q_{c}{ }^{M}$, beyond which the slope of the cathodic dissolution curve deviates from that of the theoretical $\mathrm{Co}_{3} \mathrm{O}_{4}$ dissolution curve, both increase with the potential of film formation. As shown below, these two charges $Q_{\mathrm{c}}{ }^{0}$ and $Q_{\mathrm{c}}{ }^{\mathrm{M}}$ may be used to estimate the nonstoichiometric composition of the anodic oxide films.

\section{Discussion}

The anodic oxide film in passive region $I$.-As shown in Fig. 7, an anodic, prepassive oxide film begins to form at a critical potential of about $+0.15-0.059 \mathrm{pH}$ $\left(\mathrm{V}_{\mathrm{SHE}}\right)$, where cobalt is in the active state (Fig. 1 and 2). This critical potential is close to the equilibrium potentials (13-15) for the anodic formation of $\mathrm{CoO}, \alpha-\mathrm{Co}(\mathrm{OH})_{2}$, and $\beta-\mathrm{Co}(\mathrm{OH}): E_{\mathrm{eq}}(\mathrm{Co} / \mathrm{CoO})=$ 
$+0.135-0.059 p \mathrm{H} \quad\left(\mathrm{V}_{\mathrm{SHE}}\right), \quad E_{\mathrm{eq}}\left(\mathrm{Co} / \alpha-\mathrm{Co}(\mathrm{OH})_{2}\right)=$ $+0.15-0.059 \mathrm{pH}\left(\mathrm{V}_{\mathrm{SHE}}\right)$, and $E_{\mathrm{eq}}\left(\mathrm{Co} / \beta-\mathrm{Co}(\mathrm{OH})_{2}\right)=$ +0.08-0.059 pH ( $\mathrm{V}_{\mathrm{SHE}}$ ). This prepassive oxide film, which is assumed to be $\mathrm{CoO}$ or $\mathrm{Co}(\mathrm{OH})_{2}$, grows to be the primary oxide film in passive region $I$. The fact that the galvanostatic cathodic reduction of the film formed in passive region I does not produce any detectable amount of cobalt(II) ions in the solution (Fig. 8) provides indirect evidence for a cobalt(II) oxide or hydroxide film, which is reduced to metallic cobalt at cathodic potentials.

It is also shown in Fig. 7 that the amount of anodic charge for the primary oxide film in passive region I is almost constant at $2 \sim 2.5 \mathrm{mC} / \mathrm{cm}^{2}$ in the $p \mathrm{H}$ range from 7 to 10 , which corresponds to the thickness of $12 \sim 15 \AA$ for a film of $\mathrm{CoO}$ (density $5.7 \sim 6.7 \mathrm{~g} / \mathrm{cm}^{3}$ ) and $27 \sim 33 \AA$ for a film of $\mathrm{Co}(\mathrm{OH})_{2}$ (density 3.6 $\mathrm{g} / \mathrm{cm}^{3}$ ) with the roughness factor of the surface $\gamma=1$. In the previous paper (12) the film thickness in region I has been estimated by ellipsometry to be about $25 \AA$, which is close to the thickness calculated above for $\mathrm{Co}(\mathrm{OH})_{2}$ rather than $\mathrm{CoO}$. It thus appears that the anodic oxide film in passive region I is hydrated.

There is a slight increase in both dissolution current $i_{a}$ (Fig. 1 and 2) and film charge $Q_{\mathrm{f}}$ at potentials close to the secondary passivation potential $E_{i 2}$. This is due to the formation of a higher valence oxide, probably giving rise to the partial breakdown of the hydrated $\mathrm{CoO}$ film.

The anodic oxide flm in passive regions II and III.-The anodic oxide films in passive regions II and III are characterized by the cathodic potential decay with two potential arrests and by their cathodic dissolution as cobalt(II) ion in the first potential arrest, which suggests a two-layered film consisting of an outer layer of higher valence oxide and an inner layer of lower oxide, probably $\mathrm{CoO}$. The cathodic charge required for the first potential arrest corresponds to the reduction of a higher valence oxide layer and hence may be used as a measure of its thickness.

Figure 12 shows the cathodic charge for the first potential arrest as a function of the potential at which the anodic oxide film has been formed for $1 \mathrm{hr}$ at various $p H$ solutions. Evidently, the higher valence oxide begins to form at about $+0.75 \mathrm{~V}$ (HESS), which is consistent with the ellipsometric measurements (12). Since the higher valence oxide in passive region II has been identified as $\mathrm{Co}_{3} \mathrm{O}_{4}$ (Fig. 11), this critical potential is represented by $E_{\mathrm{CoO} / \mathrm{Co}_{3} \mathrm{O}_{4}}=+0.75 \mathrm{~V}-0.059$ $p \mathrm{H}\left(\mathrm{V}_{\mathrm{SHE}}\right)$, which is compared with the equilibrium potential (13), $E_{\text {eq }}\left(\mathrm{CoO} / \mathrm{Co}_{3} \mathrm{O}_{4}\right)=+0.65-0.059 \mathrm{pH}$ $\left(\mathrm{V}_{\mathrm{SHE}}\right)$. The secondary passivation potential, $E_{\mathrm{p} 2}=$ $+0.85-0.059 \mathrm{pH}\left(\mathrm{V}_{\mathrm{SHE}}\right)$, is $0.1 \mathrm{~V}$ more anodic than

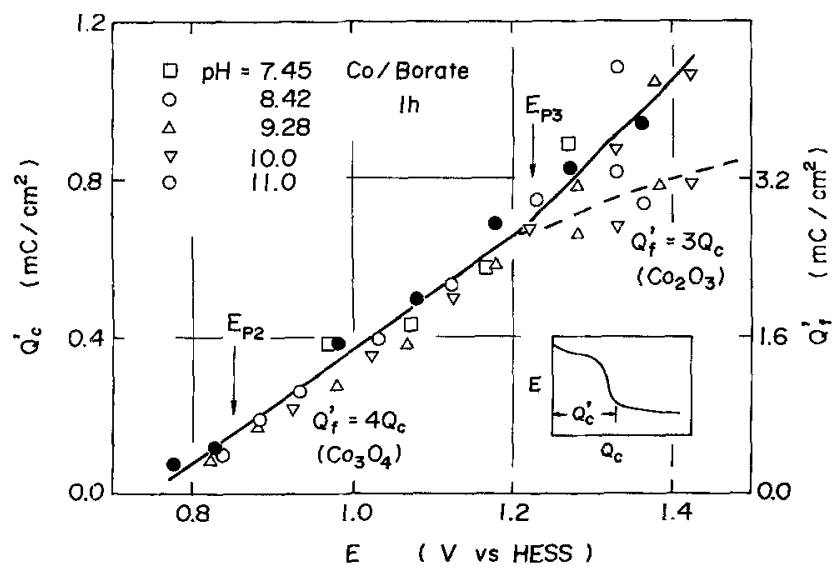

Fig. 12. Cathodic charge $Q_{c}^{\prime}$ for first potential arrest in cathodic reduction curves and anodic charge $Q_{\mathrm{f}}{ }^{\prime}$ for the outer layer $\left(\mathrm{C}_{3} \mathrm{O}_{4}\right.$ or $\mathrm{Co}_{2} \mathrm{O}_{3}$ ) as a function of potential of film formation. The film, formed for $1 \mathrm{hr}$ at different $\mathrm{pH}$, is reduced by cathodic current $5 \mu \mathrm{A} / \mathrm{cm}^{2}$ in borate solution $\mathrm{pH} 6.48$.
$E_{\mathrm{CoO} / \mathrm{Co}_{3} \mathrm{O}_{4}}$, indicating that a certain thickness or coverage of the higher valence oxide layer is required for the secondary passivation to occur.

The anodic oxide film formed in passive region III exhibits an induction period in its catlodic dissolution as cobalt(II) ions (Fig. 11). This is attributed to the reduction of excess oxygen in the film

$$
\begin{aligned}
\mathrm{Co}_{3}-\Delta \mathrm{O}_{4}+\frac{8 \Delta}{3} \mathrm{H}^{+}+\frac{8 \Delta}{3} & e \\
\rightarrow & \left(1-\frac{\Delta}{3}\right) \mathrm{Co}_{3} \mathrm{O}_{4}+\frac{4 \Delta}{3} \mathrm{H}_{2} \mathrm{O}
\end{aligned}
$$

where $\Delta$ denotes the nonstoichiometry of $\mathrm{Co}_{3} \mathrm{O}_{4}$. It is thus assumed that the cathodic charge $Q_{c}{ }^{\circ}$ required for the induction period corresponds to the amount of nonstoichiometry $\Delta$ and that the cathodic charge $Q_{c}{ }^{M}$ (Fig. 11) is equivalent to the coulomb required for the dissolution of $\mathrm{Co}_{3-\Delta} \mathrm{O}_{4}$ to cobalt(II) ions. Then, the nonstoichiometry $\Delta$ may be estimated from $Q_{c}{ }^{\circ}$ and $Q_{c}{ }^{M}$ by use of the relation $Q_{c}{ }^{\circ} / Q_{c}{ }^{M}=4 \Delta /(3+$ $3 \Delta)$. Figure 13 shows $Q_{c}{ }^{\circ} / Q_{c}{ }^{M}$ and $\Delta$ as a function of potential for the film formed at $p H$ 8.42. The nonstoichiometry $\Delta$ is seen to change from $\Delta=0$ to $\Delta=0.33$ and hence the oxidation state of the film from $\mathrm{Co}_{3} \mathrm{O}_{4}$ to $\mathrm{Co}_{2} \mathrm{O}_{3}$ at about $+1.2 \mathrm{~V}$ (HESS). This potential agrees with the critical potential that separates passive region II from passive region III in the anodic dissolution curve (Fig. 2) ; $E_{p 3}=+1.25-$ $0.059 \mathrm{pH}\left(\mathrm{V}_{\mathrm{SHE}}\right)$. The corresponding equilibrium potential (13) is $E_{\mathrm{eq}}\left(\mathrm{Co}_{3} \mathrm{O}_{4} / \mathrm{CoOOH}\right)=+1.15-0.059 \mathrm{pH}$ $\left(\mathrm{V}_{\mathrm{SHE}}\right)$. It has been shown in the previous paper (12) that the optical constant of the outer layer of the film also changes at this critical potential $E_{\mathrm{p} 3}$.

The anodic charge $Q_{f}^{\prime}$ for the higher valence oxide layer is estimated from the cathodic charge $Q_{c}^{\prime}$ required to reduce it to cobalt(II) aquo-ions, as shown in Fig. 12. The layer thickness is calculated from $Q_{\mathrm{f}}{ }^{\prime}$ by using the thickness/coulomb ratio $5.11 \AA / \mathrm{mC}$ for $\mathrm{Co}_{3} \mathrm{O}_{4}$ (density $6.1 \mathrm{~g} / \mathrm{cm}^{3}$ ) and $5.53 \AA / \mathrm{mC}$ for $\mathrm{Co}_{2} \mathrm{O}_{3}$ (density $5.2 \mathrm{~g} / \mathrm{cm}^{3}$ ). Furthermore, substraction of $Q_{\mathrm{f}}{ }^{\prime}$ from the total film charge $Q_{\mathrm{f}}$ (Fig. 7) gives the anodic charge for the inner $\mathrm{CoO}$ layer, which then allows the inner layer thickness to be computed. The thickness of both layers thus estimated for the anodic oxide
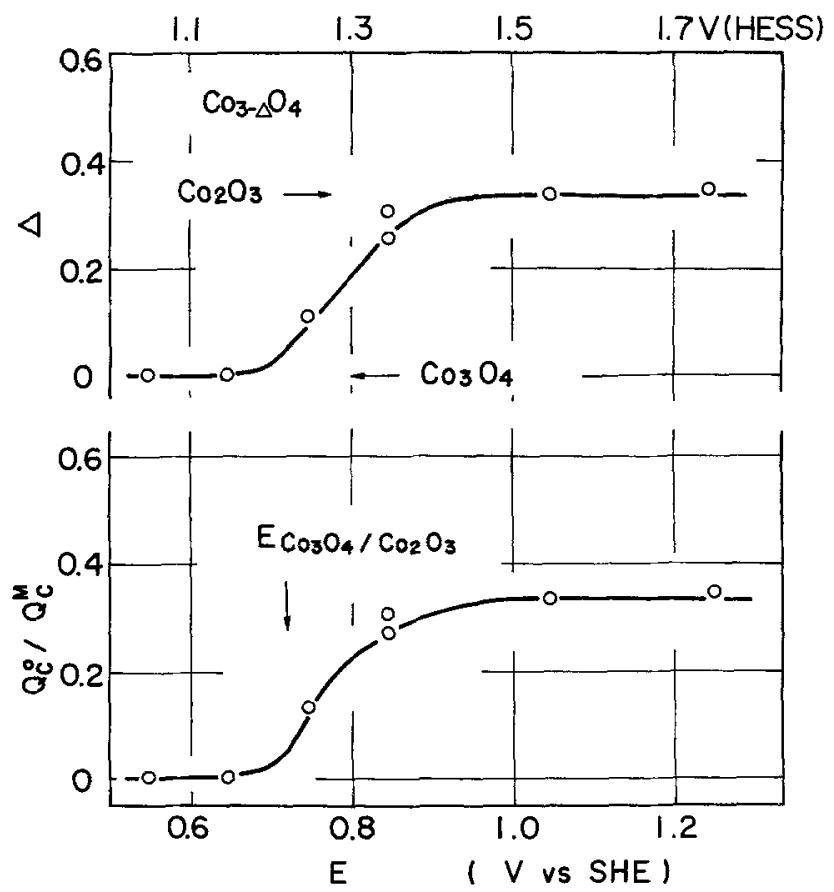

Fig. 13. Ratio $Q_{c} / Q_{c} M$ in cathodic reduction curves and nonstoichiometry $\Delta$ of the outer $\mathrm{C}_{0_{3-\Delta} \mathrm{O}_{4}}$ layer of anodic oxide films as a function of potential of film formation. 


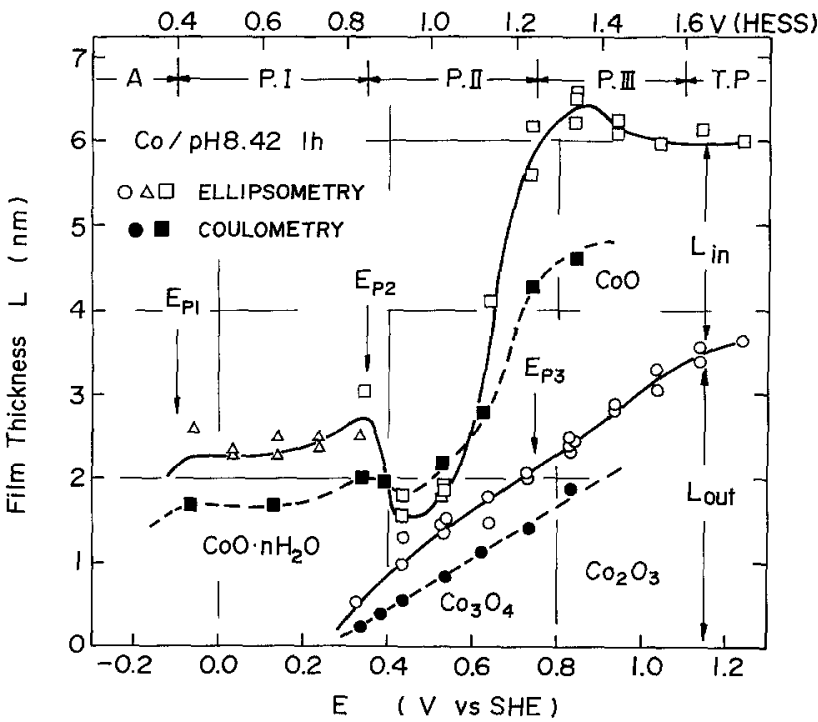

Fig. 14. Thickness/potential curves for anodic oxide films formed on cobalt for $1 \mathrm{hr}$ in borate solution $\mathrm{pH} 8.42 ; L_{\text {in }}$ represents the inner $\mathrm{C}_{0} \mathrm{O}$ layer and $\mathrm{L}_{\text {out }}$ the outer layer.

film formed at $p \mathrm{H} 8.42$ is shown in Fig. 14, where the ellipsometrically estimated thickness is also shown for comparison. Notice that the coulometric thickness estimation assumes anhydrated oxide films and hence would give a smaller thickness than expected for hydrated oxide films. The main reason for the discrepancy between the coulometric and ellipsometric thicknesses is probably the hydrated nature of the anodic oxide films.

\section{Conclusion}

1. The anodic oxidation of cobalt in borate solutions of $p H 7 \sim 11$ gives rise to the active dissolution, the passivation, and the transpassivation, depending on the potential.

2. The passive potential range can be divided into the three regions; the primary passivity (region I), the secondary passivity (region II), and the tertiary passivity (region III).

3. In region $\mathrm{I}$, which extends from $+0.4-0.059 \mathrm{pH}$ ( $\mathrm{V}_{\text {SHE }}$ ) to $+0.8-0.059 \mathrm{pH}$ (V $\mathrm{V}_{\mathrm{SHE}}$ ), a hydrated cobalt (II) oxide about $25 \AA$ thick is formed at $p H 7 \sim$ 10 , and the dissolution current $i_{p 1}$ nearly independent of potential decreases with increasing $p H ; \log i_{\mathrm{p} 1} / \mathrm{A}$ $\mathrm{cm}^{-2}=-0.44-0.63 \mathrm{pH}$ in $1 \mathrm{hr}$ oxidation.

4. In region II from $+0.9-0.059 \mathrm{pH}\left(\mathrm{V}_{\mathrm{SHE}}\right)$ to $+1.3-$ $0.059 \mathrm{pH}\left(\mathrm{V}_{\mathrm{SHE}}\right)$, an oxide or hydrated oxide film of $\mathrm{Co}_{3} \mathrm{O}_{4}$, whose thickness increases with potential up to $15 \AA$, is formed on the $\mathrm{CoO}$ film, and the dissolution current $i_{\mathrm{p} 2}$ is much smaller than $i_{\mathrm{p} 1} ; \log i_{\mathrm{p} 2} / \mathrm{A} \mathrm{cm}^{-2}$ $=-7.5$ at $\mathrm{pH} 8.42$ in $24 \mathrm{hr}$ oxidation. The total film thickness is estimated to increase from 15 to $50 \AA$ with potential.
5. In region III more anodic than $+1.3-0.059 \mathrm{pH}$ $\left(\mathrm{V}_{\mathrm{SHE}}\right)$, an oxide or hydrated oxide film of $\mathrm{Co}_{2} \mathrm{O}_{3}$, whose thickness increases with potential from 15 to $35 \AA$, is formed on the $\mathrm{CoO}$ film, and the dissolution current $i_{\mathrm{p} 3}$ is smaller than $i_{\mathrm{p} 2} ; \log i_{\mathrm{p} 3} / \mathrm{A} \mathrm{cm}^{-2}=-8.0$ at $\mathrm{pH} 8.42$ in $24 \mathrm{hr}$ oxidation.

6. The transpassive dissolution begins to occur at about +1.1 ( $\left.\mathrm{V}_{\mathrm{SHE}}\right)$ nearly independent of $\mathrm{pH}$, and the anodic oxide film in the transpassive region is the same in composition as that in passive region III.

7. The anodic oxygen evolution begins to occur at +1.4-0.059 $\mathrm{pH}$ ( $\mathrm{V}_{\mathrm{SHE}}$ ), irrespective of the passive and transpassive dissolution of cobalt.

8. The passive oxide films can be cathodically reduced to obtain an oxide-free cobalt surface. In borate solution at $p H$ 6.48 , the cathodic current of $5 \mu \mathrm{A} / \mathrm{cm}^{2}$ reduces the outer $\mathrm{Co}_{2} \mathrm{O}_{3}$ layer to a $\mathrm{Co}_{3} \mathrm{O}_{4}$ layer, which is then reduced to $\mathrm{Co}^{2+}$ ions at the differential current efficiency $\eta=100 \%$ before the onset of the reduction of the inner $\mathrm{CoO}$ layer to metallic cobalt.

Manuscript submitted March 21, 1978; revised manuscript received May 30, 1978.

Any discussion of this paper will appear in a Discussion Section to be published in the June 1979 JournaL. All discussions for the June 1979 Discussion Section should be submitted by Feb. 1, 1979.

Publication costs of this article were assisted by Hokkaido University.

\section{REFERENCES}

1. H. G. Byers, J. Am. Chem. Soc., 30, 1718 (1908); H. G. Byers and C. W. Thing, ibid., 41, 1902 (1919).

2. G. Grube and O. Feucht, $Z$. Elektrochem., 28, 568 (1922); Von G. Grube, ibid., 33, 389 (1927).

3. S. E. S. El-Wakkad and A. Hickling, Trans. Faraday Soc., 46, 1820 (1950).

4. M. H. Tikkanen and T. Tuominen, in "Proceedings 3rd International Congress on Metallic Corrosion," Vol. I, p. 489, MIR, Moscow (1969).

5. R. D. Cowling and A. C. Riddiford, Electrochim. Acta, 14, 981 (1969).

6. W. K. Behl and J. E. Toni, Electroanal. Chem. Interfacial Electrochem., 31, 63 (1971).

7. T. R. Jayaraman, V. K. Venkatesan, and H. V. K. Udupa, Electrochim. Acta, 20, 209 (1975).

8. H. Göhr and E. Lange, Z. Elektrochem., 50, 814 (1952).

9. E. Deltombe and M. Pourbaix, in "Proceedings of 6 th Meeting CITCE," p. 153, Butterworths, London (1955).

10. H. Leidheiser, Jr., G. W. Simmons, and E. Kellerman, This Journal, 120, 1516 (1973)

11. G. W. Simmons, E. Kellerman, and H. Leidheiser, ibid., 123, 1276 (1976).

12. K. Kudo, N. Sato, and T. Ohtsuka, in "Proceedings of the 4th International Passivity Symposium," ECS Publication in Press (1978).

13. H. Göhr, Electrochim. Acta, 11, 827 (1966).

14. W. Feitknecht and P. Shindler, Pure Appl. Chem., 6,130 (1963).

15. K. H. Gayer and A. B. Garret, J. Am. Chem. Soc., 72, 3971 (1950). 